\title{
Molecular markers based on sequence variation in BoFLC1.C9 for characterizing early- and late-flowering cabbage genotypes
}

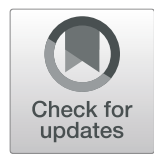

Md. Abuyusuf ${ }^{1,2}$, Ujjal Kumar Nath ${ }^{1,3}$, Hoy-Taek Kim ${ }^{1,4}$, Md. Rafiqul Islam ${ }^{1}$, Jong-In Park ${ }^{1 *}$ and III-Sup Nou ${ }^{1 *}$ (D

\begin{abstract}
Background: Cabbage (Brassica oleracea var. capitata) is popular worldwide for consumption as a leafy vegetable. Premature flowering is triggered by low temperature, and deteriorates quality of cabbage as vegetable. In general, growers prefer late-flowering varieties to assure good quality compact head. Here, we report BOFLC1.C9 as a gene with clear sequence variation between cabbage lines with different flowering times, and proposed as molecular marker to characterize early- and late-flowering cabbage lines.
\end{abstract}

Results: We identified sequence variation of 67 bp insertions in intron 2, which were contributed in flowering time variation between two inbred lines through rapid down-regulation of the BoFLC1.C9 gene in early-flowering line compared to late-flowering one upon vernalization. One set of primer 'F7R7' proposed as marker, of which was explained with 83 and $80 \%$ of flowering time variation in $141 \mathrm{~F}_{2}$ individuals and 20 commercial lines, respectively.

Conclusions: This F7R7 marker could be used as genetic tools to characterize flowering time variation and to select as well to develop early- and late-flowering cabbage cultivars.

Keywords: F7R7 marker, FLC, Early- and late-flowering, Cabbage

\section{Background}

Cultivated as a leafy vegetable, cabbage belongs to the Brassicaceae family and is popular worldwide. Flowering makes rapid elongation of the stem linked to the development of an indeterminate inflorescence [1] and the crucial transition from the vegetative phase to the reproductive phase of the plant's life cycle [2], which reduces its market quality and consumer preference. Early-flowering at premature condition leads in reduction of yield and commercial values. Therefore, vegetable growers prefer late-flowering varieties to produce high quality and economically valuable vegetables $[3,4]$. Considering the value of early- and late-flowering cabbage varieties, it is important to predict flowering time before planting. The genetic features of flowering pathways, which are mediated by environmental signals, have been previously well characterized in Arabidopsis thaliana [5, 6].

\footnotetext{
*Correspondence: jipark@sunchon.ac.kr; nis@sunchon.ac.kr

'Department of Horticulture, Sunchon National University, 255 Jungang-ro,

Suncheon, Jeonnam 57922, Republic of Korea

Full list of author information is available at the end of the article
}

The FLOWERING LOCUS T (FT), SUPPRESSOR OF OVEREXPRESSION OF CONSTANS1 (SOC1), and $L E A F Y(L F Y)$ genes are characterized through functional analysis and denoted as the main floral integrators [7-9]. $F T$ acts as florigen and this protein is conserved in the most flowering plants [10]. SOC1 and the transcription factor $L F Y$ encoding MADS-box protein, of which act as floral activator for controlling floral patterning and floral meristem to identity the male and female reproductive organs during the process of flower development [11-13]. In Brassicaceae, expression of the key gene FLOWERING LOCUS $C(F L C)$ is regulated by the perception of vernalization (passing the vegetative phase at low temperature for certain duration) [14, 15]. MADS-box transcription factor is encoded by the $F L C$ genes and repressed flowering of the plants through inhibiting downstream floral integrator genes [6, 16-20].

Brassica plants showed natural variation in flowering time, which provides an excellent resource for explaining the molecular mechanism behind it. In B. oleracea, four

(c) The Author(s). 2019 Open Access This article is distributed under the terms of the Creative Commons Attribution 4.0 International License (http://creativecommons.org/licenses/by/4.0/), which permits unrestricted use, distribution, and reproduction in any medium, provided you give appropriate credit to the original author(s) and the source, provide a link to the Creative Commons license, and indicate if changes were made. The Creative Commons Public Domain Dedication waiver (http://creativecommons.org/publicdomain/zero/1.0/) applies to the data made available in this article, unless otherwise stated. 
BoFLCs have been identified [21], but differences in the alleles of these $F L C$ genes have not been confirmed; thus it is unknown how they were contributed in variation of flowering time? A functional allele of BoFLC2 was identified in an annual Brassica [15], the mutant allele boflc2 explained the role of FLC in B. oleracea and Arabidopsis. A recent study on sequence polymorphism of four $F L C$ paralogs in B. oleracea indicated that they are not candidate in flowering time variation [22].

Many crops of $B$. oleracea species show remarkable morphological diversity and popular for their diverse edible parts, like inflorescences, axillary buds, leaves and stems [23]. Presently, two reference genomes of B. oleracea are available $[24,25]$, however based on only one reference sequence is not enough to collect the entire gene repertoire in the species, like structural variants, presence/absence variants (PAVs) and copy number variants [26-28]. A pangenome has been published for explaining such variation in B. oleracea [23]. Tettelin et al. [29] introduced the concept of pangenome in 2005 for full genomic makeup of a given species, which represents possible structural variation absent in the reference sequence.

To date, there has been little analysis of the molecular markers involved in the variation of flowering time by $F L C$ in cabbage (a sub-family member of B. oleracea). Herein, we propose molecular markers based on pangenome data of flowering integrator genes of $B$. oleracea for characterization of early- and late-flowering genotypes before planting in the field.

\section{Results}

Selection of the genes and their phylogenetic positions The AtFLC and central floral integrator genes of Arabidopsis thaliana [AtFT, AtSOC1, AtLFY, AtCO (CONSTANS LIKE), AtVRN (VERNALIZATION), AtSVP (SHORT VEGETATIVE PHASE) and AtSPL (SQUAMOSA PROMOTER BINDING LIKE)] sequences were collected from TAIR (https://www.arabidopsis.org/) and a syntenic gene search for B. oleracea using the BRAD database (http://brassicadb.org/brad/) retrieved syntenic genes of BolFLC, BolFT, BolSOC1, BolLFY, BolCO, BolVRN, BolSVP, and BolSPL. The genes were also cross-checked in the Bolbase (http://www.ocri-genomics. org/bolbase/genes.htm). Finally, Hidden Markov Models (HMM) profiling against EnsemblPlants (http://plants. ensembl.org/) and Bolpangenome (http://www.brassica genome.net/) revealed 3, 2, 3, 1, 6, 3, 2 and, 5 BoFLC, BoFT, BoSOC1, BoLFY, BoCO, BoVRN, BoSVP, and $B o S P L$ genes, respectively in $B$. oleracea (Table 1 ).

\section{Analysis of sequences and similarity of BoFLC, and integrator genes}

The structures of the selected twenty five genes were accomplished to know their protein length, locations on chromosomes, and distribution of domains (Table 1). Our analysis showed that the genes contained; MADS-box, K-box, MADS MEF2-like, MADS AFFECTING FLOWERING 5-like isoform X1, Phosphatidylethanolamine-binding protein, Floricaula/ Leafy protein, SAM, DNA-binding C-terminal, B-box type zinc finger protein with CCT, CONSTANS-LIKE 14, CONSTANS-LIKE 3, B3 domain-containing transcription factor VRN1, VEFS-Box of polycomb protein, and Squamosa promoter-binding-like protein domains. We also searched Ensembl Plants (https://plants. ensembl.org/index.html) to identify the ortholog sequences of these genes, and calculated their percent identity, query coverage, and gene order conservation (GOC) with $A$. thaliana and B. napus (Additional file 1: Table S1).

\section{Detection of DNA polymorphism in the selected gene}

PCR (polymerase chain reaction) was used to amplify gene-specific forward and reverse primer pairs covering the promoter ( $1000 \mathrm{bp}$ at the 3' UTR; untranslated region) to the stop codon of each of the genes (BoFLC, BoFT, BoSOC1, BoLFY, BoCO, BoVRN, BoSVP, and $B o S P L)$. Different combinations of the designed primer pairs were used to detect any size polymorphism in PCR amplicons between early- and late-flowering cabbage lines. However, no size polymorphism was detected for most of the genes (Additional file 2: Figure S1 and Additional file 3; for BoFLC genes as representation), except in BoFLC1.C9. Further, we analyzed details of the BoFLC1.C9 gene to confer the nature of polymorphism. By using primer sets F7R7 with expected product sizes of $438 \mathrm{bp}$, revealed distinct size polymorphisms with insertion/deletion (Indel) mutations in the second intron (Fig. 1, Table 2).

\section{Cloning, sequencing, and sequence alignment}

PCR amplicons from early- and late-flowering lines were cloned, sequenced and aligned to detect the number and position of the sequence polymorphism. Alignment of cloned sequences against the reference genes confirmed the presence of a 67-bp insertion in the second intron of early-flowering BN623 line at 2711-2712 bp position only for BoFLC1.C9 (Additional file 2: Figure S2).

This mutation of the target gene may have altered gene expression and flowering time. We analyzed the second intron of BoFLC1.C9 (Bo9gl73400) because of the presence of a $67 \mathrm{bp}$ insertion in the second intron in the early-flowering line BN623. We found inserted conserved segments of 'A' and ' $\mathrm{F}$ ' of intron 1 of AtFLC sequence, of which contains the six segments $\mathrm{A}-\mathrm{F}$, in the second intron of BoFLC1.C9 (Fig. 2), which reported as the suppressor of FLC gene [30] and produce early-flowering. 
Table 1 In silico analysis of 25 flowering pathway genes collected from the Bolpangenome database for their protein length, chromosomal location (based on the Bolpangenome and EnsemblPlants database), and distribution of domains for each gene

\begin{tabular}{|c|c|c|c|c|c|}
\hline \multirow[t]{2}{*}{ Gene Name } & \multirow[t]{2}{*}{ ID } & \multirow[t]{2}{*}{ Protein (aa) } & \multicolumn{2}{|l|}{ Chromosomal Location } & \multirow[t]{2}{*}{ Domains } \\
\hline & & & Bolpangenome & Ensemblplants & \\
\hline BoFLC1.C9 & Bo9g173400 & 197 & C9:54424498-54,428,601 (+) & C9:51033935-51,038,038 (+) & MADS-box superfamily, K-box, MADS MEF2-like \\
\hline BoFLC3.C3 & Bo3g005470 & 197 & C3:2396772-2,400,061 (-) & C3:2126639-2,129,928 (-) & MADS-box, K-box, MADS MEF2-like \\
\hline BOFLC4.C3 & Bo3g 100540 & 200 & C3:39412762-39,416,761 (-) & C3:35746750-35,750,749 (-) & $\begin{array}{l}\text { MADS AFFECTING FLOWERING 5-like isoform X1, } \\
\text { MADS-box, K-box }\end{array}$ \\
\hline BOFT.C5 & Bo5g025100 & 174 & C5: 9412613-9,414,217 (-) & C5: 8644739-8,646,343(-) & Phosphatidylethanolamine-binding protein \\
\hline BOFT.C8 & Bo8g 104520 & 173 & C8: 39187856-39,190,040 (+) & C8: 36663547-36,665,731(+) & Phosphatidylethanolamine-binding protein \\
\hline BoSOC1.C3 & Bo3g038880 & 213 & C3: 17200121-17,202,561 (-) & C3: 15404837-15,407,277(-) & MADS MEF2-like \\
\hline BOSOC1.1.C4 & Bo4g024850 & 213 & C4: 4425685-4,428,128 (-) & C4: 4021498-4023,941(-) & MADS MEF2-like \\
\hline BoSOC1.2.C4 & Bo4g195720 & 213 & C4: 56667209-56,669,626 (-) & C4: 53015176-53,017,593(-) & MADS MEF2-like \\
\hline BOLFY.C2 & Bo2g161690 & 419 & C2: 54420229-54,422,778 (+) & C2: 50956976-50,959,525(+) & $\begin{array}{l}\text { Floricaula/Leafy protein, MADS-box, } \\
\text { SAM domain, DNA-binding C-terminal domain }\end{array}$ \\
\hline BoCO.C1 & Bo1g105550 & 386 & C1:34487516-34,488,935 (-) & C1: 32389932-32,391,351 (-) & B-box type zinc finger protein with CCT domain \\
\hline BoCO.C3 & Bo3g143010 & 416 & C3:55639220-55,641,018 (-) & C3: 51379117-51,380,915 (-) & Zinc finger protein CONSTANS-LIKE 14 \\
\hline BoCO.1.C4. & Bo4g002240 & 373 & C4:157832-159,255 (-) & C4: $153423-154,846(-)$ & B-box type zinc finger protein with CCT domain \\
\hline BoCO.2.C4 & Bo4g156090 & 313 & C4:45306026-45,307,048 (+) & C4: 42763759-42,764,781 (+) & zinc finger protein CONSTANS-LIKE 3 \\
\hline BoCO.C5 & Bo5g073010 & 314 & C5:26092051-26,093,117 (-) & C5: 24568350-24,569,416 (-) & B-box type zinc finger protein with CCT domain \\
\hline BoCO.C9 & Bo9g163730 & 366 & C9:51326692-51,327,979 (+) & C9: 48282585-48,283,872 (+) & B-box type zinc finger protein with CCT domain \\
\hline BoVRN1.C1 & Bolg115980 & 343 & C1:37054708-37,057,372(+) & C1: 34825349-34,828,013 (+) & B3 domain-containing transcription factor VRN1 \\
\hline BOVRN2.C8 & Bo8g045980 & 437 & C8:16005186-16,007,664 (-) & C8: 15423858-15,426,336 (-) & VEFS-Box of polycomb protein \\
\hline BoVIN3.C3 & Bo3g095330 & 428 & C3:38317563-38,318,923 (+) & C3: $34746716-34,748,076(+)$ & Oberon, PHD finger domain \\
\hline BOSVP.C4 & Bo4g149800 & 241 & C4:43101011-43,103,883(+) & C4: 40723422-40,726,294 (+) & MADS-box protein SVP-like \\
\hline BOSVP.C8 & Bo8g101000 & 241 & C8:37659626-37,662,686 (-) & C8: 35302475-35,305,535 (-) & MADS-box protein SVP \\
\hline BOSPL.C2 & Bo2g062840 & 333 & C2:20199281-20,200,431 (+) & C2: $18471026-18,472,176(+)$ & $\begin{array}{l}\text { Squamosa promoter-binding-like } \\
\text { protein } 6 \text { isoform } X 1\end{array}$ \\
\hline BOSPL.C4 & Bo4g042390 & 157 & C4:10309157-10,309,713(-) & C4: $9471445-9,472,001(-)$ & Squamosa promoter-binding-like protein \\
\hline BoSPL.1.C6 & Bo6g029290 & 183 & C6:7117888-7,118,508 (+) & C6: 6726669-6,727,289 (+) & Squamosa promoter-binding-like protein \\
\hline BoSPL.2.C6 & Bo6g031220 & 179 & C6:7920394-7,921,332 (+) & C6: 7482570-7,483,508 (+) & Squamosa promoter-binding-like protein \\
\hline BOSPL.C8 & Bo8g118210 & 335 & C8:44900056-44,901,763 (+) & C8: 41670596-41,672,303 (+) & $\begin{array}{l}\text { Squamosa promoter binding protein-like } \\
\text { protein } 8\end{array}$ \\
\hline
\end{tabular}

Intron sequence variation interferes with gene expression To understand the effect of vernalization on earlyand late-flowering lines, the relative gene expression of BoFLC1.C9 (Bo9gl73400) was estimated by qPCR using cDNA synthesized from leaf samples of pre-vernalized (0 week), weekly vernalized plants (111 week) and the samples of control plants (without vernalization). In both early- and late-flowering lines, expression of BoFLC1.C9 (Bo9gl73400) decreased with increasing duration of vernalization. However, the expression of the gene in the early-flowering line was significantly lower (at least 5 times) at any given time point compared to the late-flowering line. In fact, even after 11 weeks of vernalization, the expression of this gene in the late-flowering line was never as low as in the pre-vernalized early-flowering line. In the early- and late-flowering lines, expression started to decline significantly after 3 and 6 weeks of vernalization, respectively (Fig. 3). In case of control (without vernalization), gene expression was non-significantly declined with the advance of time points (0-11 weeks) for both of the early- and late-flowering lines. In addition, unresponsiveness to the vernalization of the early-flowering line confirmed by the non-significant difference in gene expression between vernalized and non-vernalized plants at each time point. We concluded that a $67 \mathrm{bp}$ insertion in the second intron may cause a loss of normal function and lower expression of BoFLC1.C9. 


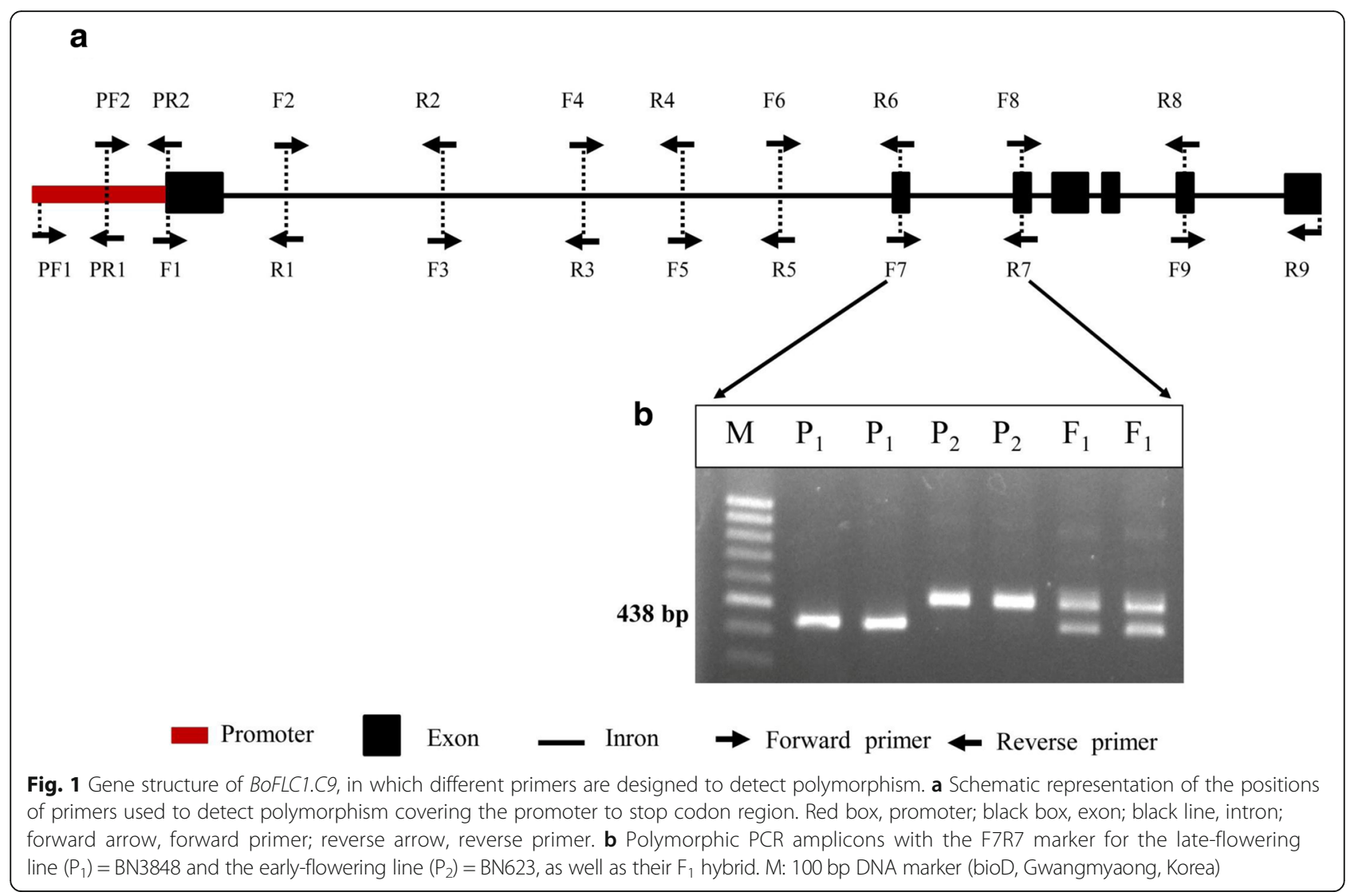

\section{Characterization of flowering time with proposed markers} in the $F_{2}$ population

We recorded the flowering times, which were 140 to 150 days after sowing (DAS) for the early-flowering line BN623 and $\geq 190$ DAS for the late-flowering line BN3848, while flowering times were varied from 142 to 210 DAS in the $F_{2}$ generation (Fig. 4). Among the $F_{2}$ individuals, fraction of heterozygous plants (presence of both parental bands) showed flowering time variations between 143 to 200 DAS. Our proposed marker 'F7R7' can explained $83 \%$ of the phenotypic variations of $141 \mathrm{~F}_{2}$ individuals regarading DAS (Additional file 2: Figure S3 and S4). While, 20 commercial lines showed $80 \%$ match with this marker considering the PCR amplification of early- and late-flowering lines (Fig. 5). The marker 'F7R7' (Table 2) was designed on the BoFLC1.C9 gene, which was able to explain $83 \%$ phenotypic variations of the early- and late-flowering corresponded to PCR amplifications in the $\mathrm{F}_{2}$ generation (Additional file 2: Figure S3 and S4).

Table 2 List of primers used to follow the mutation of BoFLC1.C9 gene in parental lines, $F_{1}$ and segregating $F_{2}$ by polymerase chain reaction (PCR); and relative expression analysis of the target and Actin genes in quantitative PCR (qPCR)

\begin{tabular}{|c|c|c|c|c|c|c|}
\hline Gene name & $\begin{array}{l}\text { Accession } \\
\text { number }\end{array}$ & Primer code & Sequences $\left(5^{\prime} \rightarrow 3^{\prime}\right)$ & Product size (bp) & $\begin{array}{l}\text { Marker } \\
\text { type }\end{array}$ & References \\
\hline \multirow[t]{2}{*}{ BoFLC1.C9 } & Bo9g173400 & $\begin{array}{l}\text { F7: } \\
\text { R7: }\end{array}$ & $\begin{array}{l}\text { GGAAAGCAACATGGTGATGA } \\
\text { CATGGTGTGAACCAGAGTCC }\end{array}$ & 438 & Indel & Present study \\
\hline & & $\begin{array}{l}\mathrm{F}: \\
\mathrm{R}:\end{array}$ & $\begin{array}{l}\text { CTCTACAGCTTCTCCTCCGG } \\
\text { TGTGAACCAGAGTCCAAAGC }\end{array}$ & 119 & $\mathrm{qPCR}$ & Present study \\
\hline \multirow[t]{3}{*}{ Actin } & AF044573 & $\begin{array}{l}\text { 1F: } \\
\text { 1R: }\end{array}$ & $\begin{array}{l}\text { TTCTCTCTTCCACACGCCAT } \\
\text { CTTGTCCTGCGGGTAATTCG }\end{array}$ & 235 & & {$[62]$} \\
\hline & JQ435879 & $\begin{array}{l}2 \mathrm{~F}: \\
2 \mathrm{R}:\end{array}$ & $\begin{array}{l}\text { GTCGCTATTCAAGCTGTTCTCT } \\
\text { GAGAGCTTCTCCTTGATGTCTC }\end{array}$ & 251 & & {$[63]$} \\
\hline & XM_013753106 & $\begin{array}{l}3 F: \\
3 R:\end{array}$ & $\begin{array}{l}\text { ATCACACTITCTACAATGAGC } \\
\text { TCGTAGATTGGCACAGTGTGAG }\end{array}$ & 241 & & {$[64]$} \\
\hline
\end{tabular}






\section{Discussion}

Flowering is a multipart physiological characteristic controlled by a series of integrator genes, vernalization genes, and by the plant spending it's vegetative phase exposed to cold temperatures for a certain period. It is necessary to develop molecular markers to select early-and late-flowering cabbage lines before sowing from a breeding population. Overwinter types must be exposed to cold (vernalization) to transition from vegetative growth to flowering, but this is not obligatory for

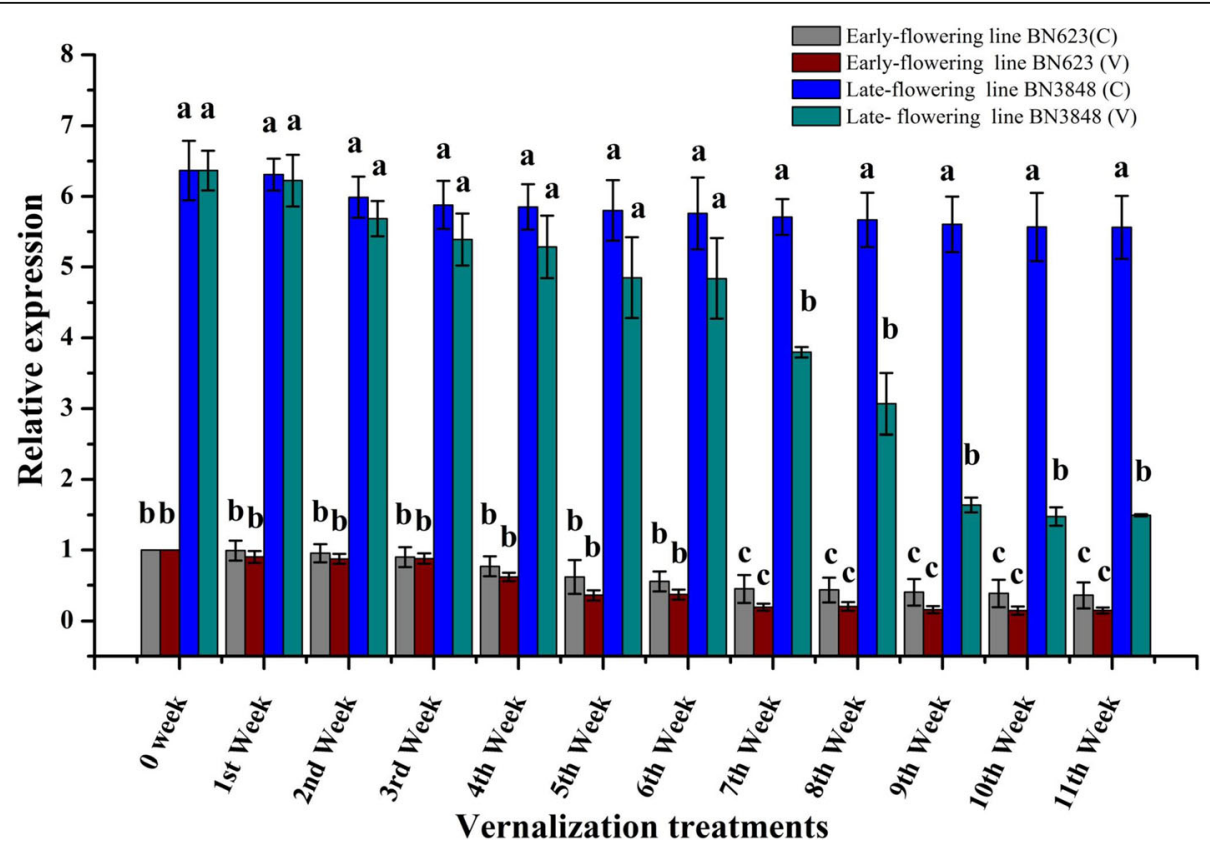

Fig. 3 Relative expression of BoFLC1.C9 using CDNA from vernalized ( $V$ ) and non-vernalized (C: control) early-flowering line BN623 and lateflowering line BN3848. Bars indicate the mean values of five replications \pm SD. Different lower case letters indicate statistically significant differences at $p<0.05$ according to Tukey's method 


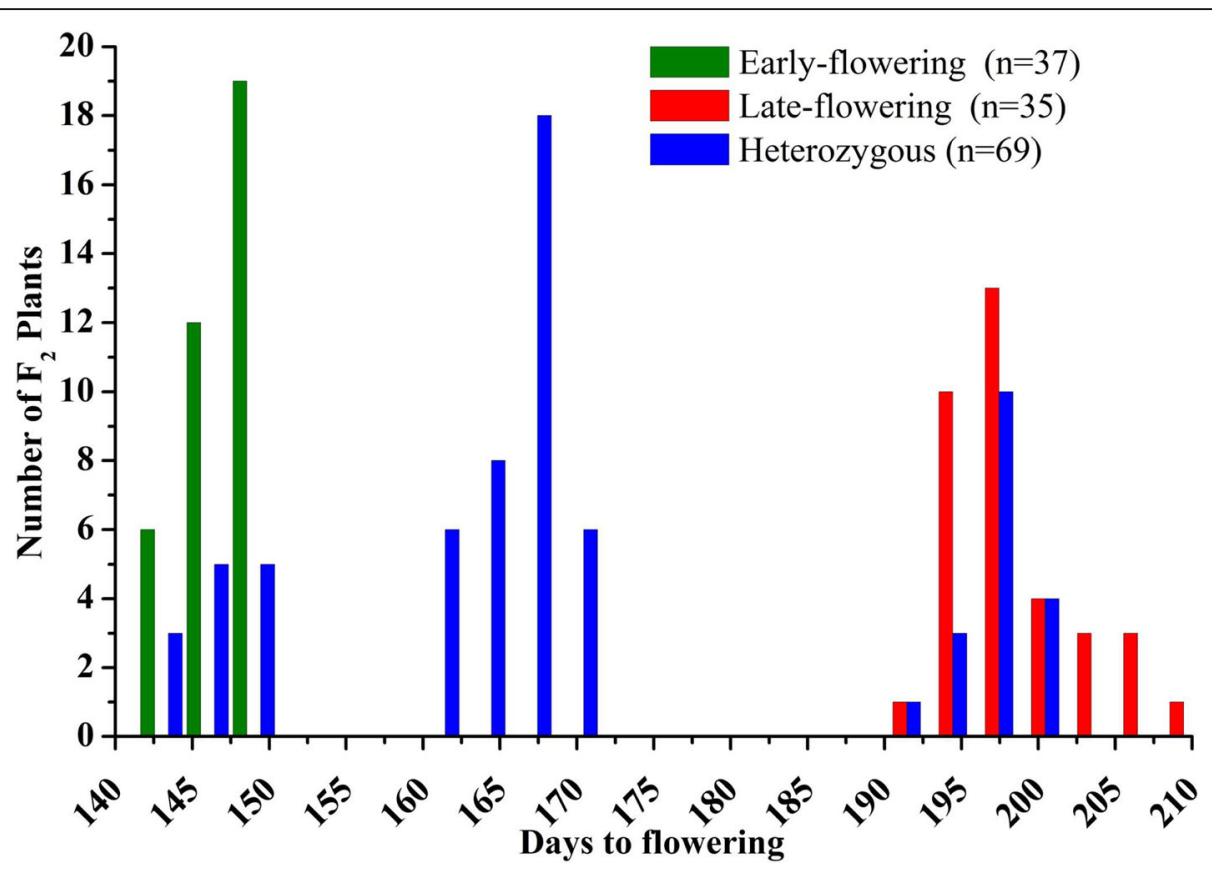

Fig. 4 Frequency distribution of phenotypes and genotype of 'F7R7' marker linked to flowering time variations in $F_{2}$ individuals

spring varieties, which are generally grown in areas with shorter seasons. Many genetic and environmental factors are involved in this transition, and signals of these factors are integrated into the causal effect of flowering [31]. Transition of flowering from vegetative phase is the resultant of the interactions between transducer proteins and integrator signals, which either promote or inhibit the transition process [10, 32]. In Arabidopsis, the key flowering genes have been identified and characterized $[6,33]$. Flowering genes are involved in a 'floral integrator' network, comprised with six regulatory gene pathways [31]. FLC is a key member of the floral integrator network, and its expression is influenced by low temperature.

There are multiple $F L C$ and 'floral integrator' homolog genes in cabbage (B. oleracea var. capitata) were duplicated before divergence of Brassica from their ancestor
[21]. The group of genes with MADS-box domains consists of five MADS AFFECTING FLOWERING (MAF) proteins [34]. FLOWERING LOCUS M (FLM, known as MAF1) represses flowering [35, 36], through vernalization dependent repression of $F L M$ and $M A F 1$ genes and accelerates flowering [37-39].

Among the selected 25 genes ( 3 BoFLC, 2 BoFT, 3 BoSOC1, 1 BoLFY, 6 BoCO, 3 BoVRN, 2 BoSVP, and 5 $B o S P L)$, we found DNA size polymorphisms only in BoFLC1.C9 (Bo9gl73400) gene between early- and late-flowering lines by using several primers at different positions. The polymorphic BoFLC1.C9 (Bo9gl73400) gene contains MADS-box and K-box domain proteins, thus it might be involved in flowering time variation in cabbage. By contrast, in the Brassicaceae, suppression of flowering is mediated by vernalization, which mainly involves major-effect changes at a few loci [40-43]. Of

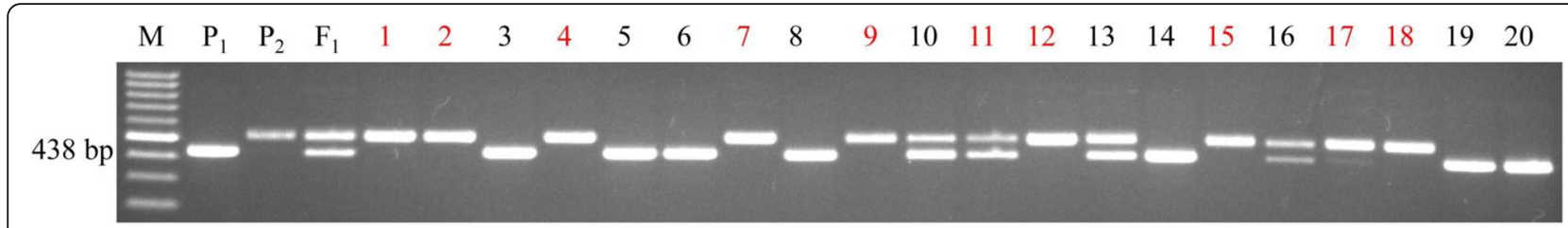

Fig. 5 Markers are validated with 20 commercial early- and late-flowering cabbage lines, with 'F7R7' marker; of BoFLC1.C9 gene matched 80\% with the lines, the heterozygous lines (lanes: 10, 11, 13, and 16) are not matched with the phenotypes exactly. Here, $P_{1}=$ late-flowering parent (BN3848), $P_{2}=$ early-flowering parent (BN623), $F_{1}=(B N 3848 \times B N 623), M=100$ bp DNA marker, Red color numbered (10 early-flowering lines): lane 1, 2, 4, 7, 9, 11, 12, 15,17 are 17 FLE1, 17 FLE2, 17 FLE3, 17 FLE4, 17 FLE5, 17 FLE6, 17 FLE7, 17 FLE8, 17 FLE9, and 17 FLE10, respectively and black color numbered (10 late-flowering lines): lanes 3, 5, 6, 8, 10, 13, 14, 16,19 and 20 are 17 FLL1, 17 FLL2, 17 FLL3, 17 FLL4, 17 FLL5, 17 FLL6, 17 FLL7, 17 FLL8, 17 FLL9, and 17 FLL10, respectively 
these, FLC appears to be the predominant source of variation in the vernalization response $[44,45]$, and ultimately causes the variation in flowering time. Association and/or quantitative trait locus (QTL) mapping corroborated that variation in flowering time of $B$. oleracea, B. rapa, and B.napus is linked to polymorphism in $F L C$ homologs and responded upon vernalization [46-49].

In BoFLC1.C9 (Bo9gl73400), the 'F7R7' marker (Table 2) showed polymorphism across intron 2. We linked this mutation with flowering time variation in the $\mathrm{F}_{2}$ population of the cross (BN3848 (late-flowering) $\times$ BN623 (early-flowering)) and twenty commercial cultivars. FRI gene was identified as a major determinant of flowering time variation in $A$. thaliana population through it's effect on $F L C$ [50, 51]. In addition, indel polymorphism of CONSTANS LIKE 1 (COL1) has also been associated with flowering time variation in B. nigra [52].

In this study, lower relative expression of the BoFLC1.C9 gene was found in the early-flowering line, where presence the Indel variation, compared to the late-flowering line (Fig. 3). The presence of spliced long noncoding RNA in COOLAIR locus of late-flowering line leading to higher $F L C$ expression and delay flowering. This is supported by the identification of a single nucleotide polymorphism (SNP) in $A$. thaliana haplotype which caused splicing of long noncoding RNA (lnRNA) at COOLAIR locus leading to higher $F L C$ expression and increased requirement for vernalization or delayed flowering [38]. COOLAIR splicing disrupted COOLAIR production due to splice at the COOLAIR proximal acceptor site [53] and suggested that splicing of InRNA could be modulated FLC expression quantitatively through co-transcriptional coupling mechanisms [53]. Conservation of COOLAIR [54] and presence of the AtFLC antisense RNA in Arabis alpine [55] and B. rapa [56] have been pointed as strong commonality in the regulation of FLC across the Brassicaceae.

Noncoding sequence alteration has recently been identified in $A t F L C$ haplotype groups with different degree of AtFLC expression and epigenetic silencing [57]. In B. oleracea, one of two major FLC haplotypes is transcriptionally repressed by exposure to cold more slowly than others [46]. Intron 2 of the BoFLC1.C9 gene might be responsible for FLC repression activities by accommodating segments of intron 1 of Arabidopsis FLC (Fig. 2). The intron 1 of Arabidopsis FLC segments are required to maintain FLC repression [30]. The segregating $F_{2}$ population showed wide range of variation in flowering time followed neither in continuous variation nor in Mendelian inheritance (Fig. 4).

Results obtained from DNA size polymorphism analysis of BoFLC1.C9 and the $\mathrm{F}_{2}$ phenotypes suggest that BoFLC1.C9 is a likely candidate for causing variation in flowering time in this population. It has previously been reported that regulation of FLC is controlled by the regions in its intron [30, 58], with polymorphisms leading to differential expression and splicing patterns. The proposed marker 'F7R7' based on $67 \mathrm{bp}$ insertion in intron 2 accounted for $83 \%$ of flowering time variation, among the $\mathrm{F}_{2}$ population. While, in commercial lines 'F7R7' makers matched up to $80 \%$. Ridge et al. [15] found $65 \%$ flowering time variation in the $F_{2}$ population of a cross of late- and early-flowering cauliflower lines. A $67 \mathrm{bp}$ insertion in the second intron of BoFLC1.C9 gene in the early bolting line made a distinct mutation and disrupted the function of the gene and showed lower expression caused early-flowering.

\section{Conclusions}

Using molecular markers and relative expression-based approaches, we reported the sequence variations in BoFLC1.C9 gene for characterizing early- and late-flowering cabbage lines. Our result suggests that naturally occurring 'Indel' confirmed by 'F7R7' marker in intron 2 in the BoFLC1.C9 gene is able to characterize early- and late-flowering cabbage lines up to $80 \%$ variation. This marker might be useful for selecting desired early- and/or late-flowering cabbage cultivars before cultivation. Further experiments on presence of copy number of BoFLC1.C9 gene could elucidate the mismatched fractions of the 'F7R7' marker more clearly.

\section{Methods}

\section{Plant materials and evaluation of flowering time}

Two inbred lines (late-flowering BN3848 and early-flowering BN623) with distinct flowering times varying by $40-45$ days, were used to develop $F_{1}$ and $F_{2}$ generation plants by crossing and selfing, respectively. The average flowering time was 140 to 150 DAS for the early-flowering line BN623 and $\geq 190$ DAS for the late-flowering line $\mathrm{BN} 43848$. The $\mathrm{F}_{1}$ generation was designated as intermediate flowering with 160-175 DAS. Whereas, twenty commercial cabbage cultivars collected from Sunchon National University Cabbage breeding germplasm, which were characterized as early-flowering (140-150 DAS) and late-flowering ( $\geq 195$ DAS). A pot-based glasshouse trial was conducted at Sunchon National University, South Korea using five plants of parental lines, five from the $F_{1}$ generation, and 141 from the $F_{2}$ generation to record variations in flowering time. Seeds of the plant materials were germinated in a multipot tray using cocopit soil, and were allowed to grow in a growth chamber at $24{ }^{\circ} \mathrm{C}, 60 \%$ relative humidity, and under $16 \mathrm{~h} / 8 \mathrm{~h}$ (light/dark) conditions for up to 60 days. Then, in September 2015, eight weeks old plants at 8 
leaf stage were transferred to larger pots $(30 \times 25 \mathrm{~cm})$ filled with a mixture of $50 \%$ cocopit and $50 \%$ soil. Plants were allowed to overwinter inside the glasshouse, where temperature and day length were recorded in the range of $-5^{\circ} \mathrm{C}$ to $8{ }^{\circ} \mathrm{C}$ with $10 \mathrm{~h} / 14 \mathrm{~h}$ (light/dark) during the winter and $12-17^{\circ} \mathrm{C}$ with $12 \mathrm{~h} / 12 \mathrm{~h}$ (light/dark) during the spring. The number of days to flowering was recorded as the day on which the first flower of individual plants was observed to open after seedlings were transplanted to larger pots in the glasshouse. Plants that did not flower within 190 days were considered to be late flowering.

\section{Gene selection and sequence analyses}

The flowering pathway gene sequences of $A$. thaliana were collected from TAIR (https://www.arabidopsis.org/) and the syntenic genes of $B$. oleracea were collected from the BRAD database (http://brassicadb.org/brad/) using syntenic gene search and cross-checked against the Bolbase (http://www.ocri-genomics.org/bolbase/ genes.htm) as well as EnsemblPlants (http://plants. ensembl.org/) databases. A complementary method, Hidden Markov Models (HMM) profiling was performed using the Bolpangenome (http://www.brassicagenome.net/) database to increase the accuracy of the identified genes. The National Center for Biotechnology Information (NCBI) (https://www.ncbi.nlm.nih.gov/ Structure/cdd/wrpsb.cgi) web tool was used for searching the domains.

\section{Isolation of DNA and detection of DNA polymorphism}

The protocol described by Ishizawa et al. [59] with slight modifications was followed for extracting DNA from four weeks leaf samples of parental lines, five $F_{1}$ plants, $141 \mathrm{~F}_{2}$ plants, and 20 commercial cultivars. Primer3Plus online tool was used for designing locus-specific primers. The newly designed and previously reported primers $[15,22,46,60]$ (listed in Table 2, and Additional file 1: Table S2A,B) were used to identify DNA polymorphisms between the contrasting lines. A total volume of $20 \mu \mathrm{l}$ was used in PCR, which contained $1 \mu \mathrm{l}$ DNA (80 $\mathrm{ng}), 1 \mu \mathrm{l}(10 \mathrm{pmol})$ of forward and $1 \mu \mathrm{l}(10 \mathrm{pmol})$ of reverse primers, $8 \mu$ l Prime Taq-premix $(2 \times)$ (GENETBIO Inc., Gwangmyaong, Korea), and $9 \mu \mathrm{l}$ ultra-pure $\mathrm{H}_{2} \mathrm{O}$. PCR was carried out in a thermo-cycler set as 5-min initial denaturation at $95^{\circ} \mathrm{C}$, followed by 30 cycles of denaturation at $95^{\circ} \mathrm{C}$ for $1 \mathrm{~min}$, annealing at $58^{\circ} \mathrm{C}$ for 1 min, elongation at $72^{\circ} \mathrm{C}$ for $1 \mathrm{~min}$, final elongation at 72 ${ }^{\circ} \mathrm{C}$ for $10 \mathrm{~min}$, and cool down at $4{ }^{\circ} \mathrm{C}$. PCR products were separated in $2 \%$ agarose gel stained with HiQ blue mango (20,000×) (bioD, Gwangmyaong, Korea) and visualized with ultraviolet light.
Cloning and sequencing of the polymorphic gene

Promega Purification Kit (Promega, Madison, WI, USA) was used for purification of the amplified DNA fragments following manufacturer's instructions. TOPO TA Cloning Kit (Invitrogen, Carlsbad, CA, USA) was used for cloning. Three independent clones were separated from the PCR amplicon of the polymorphic gene, amplified in both early- and late-flowering lines. The universal primers M13F and M13RpUC were used for sequencing the cloned DNA by using ABI3730XL sequencer (Macrogen Co., Seoul, South Korea). Cloned sequences were aligned with a reference sequence using ClustalOmega [61] to identify the types and positions of sequence variations.

\section{Isolation of RNA, synthesis of CDNA and expression profiling of the polymorphic gene}

The RNeasy Mini Kit (Qiagen, Hilden, Germany) was used for isolating total RNA from leaf samples collected from the different levels of vernalized plants, and total RNA was purified with a Qiagen RNase-free DNase1 Kit (Qiagen, Hilden, Germany). For the vernalization treatment, a set of plants at 8th leaf stage was transferred to incubators (TOGA clean system; model: TOGA UGSR01, Daejong, Korea) maintained at $4{ }^{\circ} \mathrm{C}$ with $14 \mathrm{~h} / 10 \mathrm{~h}$ (light/dark) until 11 weeks of vernalization. Leaf samples were excised from five replicated plants of prevernalized (0 week), 1-, 2-, 3-, 4-, 5-, 6-, 7-, 8-, 9-, 10-, and 11- week of vernalization and control (no vernalization) as checked. The leaf samples were immersed quickly in liquid nitrogen and stored at $-80^{\circ} \mathrm{C}$ to avoid degradation of RNA. The RNA was quantified by using NanoDrop 1000 Spectrophotometer (Wilmington, DE, USA) and $6 \mathrm{ng}$ of RNA per sample was used for synthesizing first-strand cDNA by using the Superscript ${ }^{\circ}$ III First-Strand cDNA Synthesis Kit (Invitrogen, Carlsbad, CA, USA) with oligo-dT primer. Gene-specific primers of the candidate $F L C$ (BoFLC1.C9) and Actin genes were used for $\mathrm{qPCR}$ (Table 2). A total volume $10 \mu \mathrm{l}$ PCR mastermix for each sample contained $1 \mu \mathrm{l}$ of cDNA (70 ng), $1 \mu \mathrm{l}$ (10 pmol) of each forward and reverse primer, $2 \mu$ double distilled water, and $5 \mu \mathrm{l} \mathrm{Taq}{ }^{\mathrm{ma}}$ from the $\mathrm{SYBR}^{\circ}$ Green PCR Kit (ThermoFisher, California, USA) of was used for conducting qPCR. A Lightcycler ${ }^{\circ}$ 96SW 1.1 (Roche, Dusseldorf, Germany) programmed as pre-denaturation at $95^{\circ} \mathrm{C}$ for $5 \mathrm{~min}$, followed by 40 cycles of denaturation at $94^{\circ} \mathrm{C}$ for $10 \mathrm{~s}$, annealing at $58^{\circ} \mathrm{C}$ for 10 $\mathrm{s}$, and extension at $72{ }^{\circ} \mathrm{C}$ for $15 \mathrm{~s}$ was used for carrying out the qPCR. Gene expression levels for each sample were normalized by using the average ' $\mathrm{Ct}$ ' value of the 3 Actin genes as a reference. The $2^{-\Delta \Delta C t}$ method was used to calculate relative expression [34]. 
One-way analysis of variance (ANOVA) and mean separations of the relative expression of genes were calculated using with MINITAB version 18 statistical software (Minitab Inc., State College, PA, USA).

\section{Additional files}

\begin{abstract}
Additional file 1: Table S1. Ortholog species, ortholog ID, percent identity, percent query coverage and GOC of 25 genes of BOFLC, BOFT, BOSOC1, BOLFY, BOCO, BOVRN, BOVIN, BOSVP and BOSPL of B. oleracea. Table S2 A. List of newly designed primers on the identified 25 genes used for searching polymorphism by PCR. Table S2 B. List of previously published primers on the reported FLCs in B. oleracea used in this study. (DOC $272 \mathrm{~kb}$ )
\end{abstract}

Additional file 2: Figure S1. PCR amplicons of BOFLC1.C9, BOFLC3.C3 and BoFLC4.C3 in late-flowering line BN3848 $\left(P_{1}\right)$ and early-flowering line BN623 $\left(P_{2}\right)$. PCR products with respective primers from start to stop codons of the genes (Additional file 1: Table S1A) were run on a 1.5\% agarose gel and their corresponding amplicon sizes are mentioned. $M$ is a 100-bp size marker. Figure S2. Sequence alignments of the BoFLC1.C9 gene cloned from early- and late-flowering lines. Variation of a 67-bp insertion in the early-flowering line BN623 is highlighted in red color. Figure S3. PCR-amplicons of $141 \mathrm{~F}_{2}$ segregating population with F7R7 primers of Indel marker of BoFLC1.C9 gene. $P_{1}=$ Late-flowering parent (BN3848), $P_{2}=$ Early-flowering parent $(B N 623), F_{1}=(B N 3848 \times B N 623)$; black and red colored numbers of the $\mathrm{F}_{2}$ individual are matched and mismatched lines, respectively as early- and late-flowering lines. $M=100 \mathrm{bp}$ DNA marker. Figure S4. Regression and correlation coefficient between marker dosage and phenotypes as days to flowering after sowing (DAS) explained by the F7R7 marker in $141 \mathrm{~F}_{2}$ individual. ${ }^{* *}$ indicates $p<0.01$. (PPT $2295 \mathrm{~kb}$ )

Additional file 3: Sequence alignment of the total sequences of the gene BOFLC3.C3 and BoFLC4.C3 cloned from early-flowering line (BN623) and late-flowering line (BN3848) aligned with reference sequence of BoFLC3.C3 and BoFLC4.C3 genes, respectively. Red highlighted letter indicate SNPs variations in the early-flowering line. Forward and reverse arrows indicate forward and reverse primer sets used for cloning and sequencing. (DOC $747 \mathrm{~kb})$

\section{Abbreviations}

COL1: CONSTANS LIKE 1; DAS: Days after sowing; FLC: FLOWERING LOCUS C; FLM: FLOWERING LOCUS M; FT: FLOWERING LOCUS T; GOC: Gene order conservation; Indel: Insertion/deletion; LFY: LEAFY; MAF: MADS AFFECTING FLOWERING; PAVs: Presence/absence variants; PCR: Polymerase Chain Reaction; SD: Standard deviation; SOC1: SUPPRESSOR OF OVEREXPRESSION OF CONSTANS1; SPL: SQUAMOSA PROMOTER BINDING LIKE; SVP: SHORT VEGETATIVE PHASE; UTR: Untranslated region; VRN: VERNALIZATION

\section{Acknowledgments}

We thank the Asia Seed Co., Ltd., Republic of Korea for providing B. oleracea seeds.

\section{Funding}

This research was supported by the Golden Seed Project of the Center for Horticultural Seed Development (grant number 213007-05-3-SB110), the Ministry of Agriculture, Food and Rural Affairs, the Ministry of Oceans and Fisheries, the Rural Development Administration, and the Korea Forest Service, Korea. The funding body provided monthly salary for the first two authors and who were directly involved in the design of the study and collection, analysis, and interpretation of data and in writing the manuscript.

\section{Availability of data and materials}

We declare that the dataset(s) supporting the conclusions of this article are included within the article (and its additional file(s)).

\section{Authors' contributions}

The work presented here was carried out in collaboration with all authors. MA carried out the experiments, performed in silico analyses and cloning, and prepared the tables and figures and first manuscript draft. UKN collected primary gene data and wrote, edited, and finalized the manuscript. JIP formulated the experimental concept and provided the plant materials. HTK conducted greenhouse experiments and took care of the plant populations. MRI helped to extract RNA and synthesize CDNA. ISN designed and participated in all experiments, and assisted in improving the technical aspects of the project. All authors read and approved the final manuscript.

\section{Ethics approval and consent to participate}

Not applicable.

\section{Consent for publication}

Not applicable.

\section{Competing interests}

The authors declare that they have no competing interests.

\section{Publisher's Note}

Springer Nature remains neutral with regard to jurisdictional claims in published maps and institutional affiliations.

\section{Author details}

'Department of Horticulture, Sunchon National University, 255 Jungang-ro, Suncheon, Jeonnam 57922, Republic of Korea. ${ }^{2}$ Department of Agronomy, Patuakhali Science and Technology University, Patuakhali 8602, Bangladesh. ${ }^{3}$ Department of Genetics and Plant Breeding, Bangladesh Agricultural University, Mymensingh 2202, Bangladesh. ${ }^{4}$ University-Industry Cooperation Foundation, Sunchon National University, 255 Jungang-ro, Suncheon, Jeonnam 57922, Republic of Korea.

Received: 7 September 2018 Accepted: 18 March 2019

Published online: 27 April 2019

\section{References}

1. Hébrard C, Trap-Gentil M-V, Lafon-Placette C, Delaunay A, Joseph C, Lefèbvre M, Barnes S, Maury S. Identification of differentially methylated regions during vernalization revealed a role for RNA methyltransferases in bolting. J Exp Bot. 2013;64(2):651-63.

2. Xia G, He Q, Zhao S. Physiological and biochemical properties analysis of late-bolting transgenic Chinese cabbage (Brassica rapa L. ssp. pekinensis). J Anim Plant Sci. 2015;25(Suppl. 1):152-7.

3. Mao Y, Wu F, Yu X, Bai J, Zhong W, He Y. MicroRNA319a-targeted Brassica rapa ssp. pekinensis TCP genes modulate head shape in chinese cabbage by differential cell division arrest in leaf regions. Plant Physiol. 2014;164(2): 710-20.

4. Wang Y, WU F, Bai J, He Y. BrpSPL9 (Brassica rapa ssp. pekinensis SPL9) controls the earliness of heading time in Chinese cabbage. Plant Biotechnol J. 2014;12(3):312-21.

5. Ausin I, Alonso-Blanco C, Martinez-Zapater J-M. Environmental regulation of flowering. Int J Dev Biol. 2004;49(5-6):689-705.

6. Fornara F, de Montaigu A, Coupland G. SnapShot: control of flowering in Arabidopsis. Cell. 2010;141(3):550 e552.

7. Blázquez MA, Green R, Nilsson O, Sussman MR, Weigel D. Gibberellins promote flowering of Arabidopsis by activating the LEAFY promoter. Plant Cell. 1998;10(5):791-800.

8. Nilsson O, Lee I, Blázquez MA, Weigel D. Flowering-time genes modulate the response to LEAFY activity. Genetics. 1998;150(1):403-10.

9. Samach A, Onouchi H, Gold SE, Ditta GS, Schwarz-Sommer Z, Yanofsky MF, Coupland G. Distinct roles of CONSTANS target genes in reproductive development of Arabidopsis. Science. 2000;288(5471):1613-6.

10. Andrés F, Coupland $\mathrm{G}$. The genetic basis of flowering responses to seasonal cues. Nat Rev Genet. 2012:13(9):627-39.

11. Liu C, Zhou J, Bracha-Drori K, Yalovsky S, Ito T, Yu H. Specification of Arabidopsis floral meristem identity by repression of flowering time genes. Development. 2007:134(10):1901-10.

12. Melzer S, Lens F, Gennen J, Vanneste S, Rohde A, Beeckman T. Floweringtime genes modulate meristem determinacy and growth form in Arabidopsis thaliana. Nat Genet. 2008;40(12):1489.

13. Weigel D, Alvarez J, Smyth DR, Yanofsky MF, Meyerowitz EM. LEAFY controls floral meristem identity in Arabidopsis. Cell. 1992;69(5):843-59. 
14. Kemi U, Niittyvuopio A, Toivainen T, Pasanen A, Quilot-Turion B, Holm K, Lagercrantz U, Savolainen O, Kuittinen H. Role of vernalization and of duplicated FLOWERING LOCUS C in the perennial Arabidopsis lyrata. New Phytol. 2013;197(1):323-35.

15. Ridge S, Brown PH, Hecht V, Driessen RG, Weller JL. The role of BoFLC2 in cauliflower (Brassica oleracea var. botrytis L.) reproductive development. J Exp Bot. 2014;66(1):125-35

16. Michaels SD, Amasino RM. FLOWERING LOCUS C encodes a novel MADS domain protein that acts as a repressor of flowering. Plant Cell. 1999;11(5):949-56.

17. Sheldon CC, Rouse DT, Finnegan EJ, Peacock WJ, Dennis ES. The molecular basis of vernalization: the central role of FLOWERING LOCUS C (FLC). Proc Natl Acad Sci USA. 2000;97(7):3753-8.

18. Searle I, He Y, Turck F, Vincent C, Fornara F, Kröber S, Amasino RA, Coupland $G$. The transcription factor $F L C$ confers a flowering response to vernalization by repressing meristem competence and systemic signaling in Arabidopsis. Genes Dev. 2006;20(7):898-912

19. Saha G, Park J-I, Jung H-J, Ahmed NU, Kayum MA, Chung M-Y, Hur Y, Cho Y-G, Watanabe M, Nou I-S. Genome-wide identification and characterization of MADS-box family genes related to organ development and stress resistance in Brassica rapa. BMC Genomics. 2015;16(1):178.

20. Xu Y-Y, Jing W, Nie S-S, Huang D-Q, Yan W, Liang X, Wang R-H, Luo X-B, Liu L-W. Isolation and molecular characterization of the FLOWERING LOCUS C gene promoter sequence in radish (Raphanus sativus L.). J Integr Agric. 2016;15(4):763-74.

21. Schranz ME, Quijada P, Sung S-B, Lukens L, Amasino R, Osborn TC. Characterization and effects of the replicated flowering time gene $F L C$ in Brassica rapa. Genetics. 2002;162(3):1457-68.

22. Razi H, Howell E, Newbury H, Kearsey M. Does sequence polymorphism of FLC paralogues underlie flowering time QTL in Brassica oleracea? Theor Appl Genet. 2008;116(2):179-92

23. Golicz AA, Bayer PE, Barker GC, Edger PP, Kim H, Martinez PA, Chan CKK, Severn-Ellis A, McCombie WR, Parkin IA. The pangenome of an agronomically important crop plant Brassica oleracea. Nat Commun. 2016;7:13390

24. Liu S, Liu Y, Yang X, Tong C, Edwards D, Parkin IA, Zhao M, Ma J, Yu J, Huang S. The Brassica oleracea genome reveals the asymmetrical evolution of polyploid genomes. Nat Commun. 2014;5:3930.

25. Parkin IA, Koh C, Tang H, Robinson SJ, Kagale S, Clarke WE, Town CD, Nixon J, Krishnakumar V, Bidwell SL. Transcriptome and methylome profiling reveals relics of genome dominance in the mesopolyploid Brassica oleracea. Genome Biol. 2014;15(6):R77.

26. Morgante M, Brunner S, Pea G, Fengler K, Zuccolo A, Rafalski A. Gene duplication and exon shuffling by helitron-like transposons generate intraspecies diversity in maize. Nat Genet. 2005;37(9):997.

27. Gan X, Stegle O, Behr J, Steffen JG, Drewe P, Hildebrand KL, Lyngsoe R, Schultheiss SJ, Osborne EJ, Sreedharan VT. Multiple reference genomes and transcriptomes for Arabidopsis thaliana. Nature. 2011;477(7365):419.

28. Golicz AA, Batley J, Edwards D. Towards plant pangenomics. Plant Biotechnol J. 2016;14(4):1099-105.

29. Tettelin H, Masignani V, Cieslewicz MJ, Donati C, Medini D, Ward NL, Angiuoli SV, Crabtree J, Jones AL, Durkin AS. Genome analysis of multiple pathogenic isolates of Streptococcus agalactiae: implications for the microbial "pan-genome". Proc Natl Acad Sci. 2005;102(39):13950-5.

30. Sheldon CC, Conn AB, Dennis ES, Peacock WJ. Different regulatory regions are required for the vernalization-induced repression of FLOWERING LOCUS C and for the epigenetic maintenance of repression. Plant Cell. 2002;14(10):2527-37.

31. Song X, Duan W, Huang Z, Liu G, Wu P, Liu T, Li Y, Hou X. Comprehensive analysis of the flowering genes in Chinese cabbage and examination of evolutionary pattern of CO-like genes in plant kingdom. Sci Rep. 2015;5: 14631.

32. Jung C, Müller AE. Flowering time control and applications in plant breeding. Trends Plant Sci. 2009;14(10):563-73.

33. Levy YY, Dean C. The transition to flowering. Plant Cell. 1998;10(12):1973-89.

34. Ratcliffe OJ, Kumimoto RW, Wong BJ, Riechmann JL. Analysis of the Arabidopsis MADS AFFECTING FLOWERING gene family: MAF2 prevents vernalization by short periods of cold. Plant Cell. 2003;15(5):1159-69.

35. Ratcliffe OJ, Nadzan GC, Reuber TL, Riechmann JL. Regulation of flowering in Arabidopsis by an FLC homologue. Plant Physiol. 2001;126(1):122-32.

36. Scortecci KC, Michaels SD, Amasino RM. Identification of a MADS-box gene, FLOWERING LOCUS M, that represses flowering. Plant J. 2001;26(2):229-36.
37. Werner JD, Borevitz JO, Uhlenhaut NH, Ecker JR, Chory J, Weigel D. FRIGIDAindependent variation in flowering time of natural Arabidopsis thaliana accessions. Genetics. 2005;170(3):1197-207.

38. Li Y, Roycewicz P, Smith E, Borevitz JO. Genetics of local adaptation in the laboratory: flowering time quantitative trait loci under geographic and seasonal conditions in Arabidopsis. PLoS One. 2006;1(1):e105.

39. Sung S, He Y, Eshoo TW, Tamada Y, Johnson L, Nakahigashi K, Goto K, Jacobsen SE, Amasino RM. Epigenetic maintenance of the vernalized state in Arabidopsis thaliana requires LIKE HETEROCHROMATIN PROTEIN 1. Nat Genet. 2006;38(6):706-10.

40. Anderson JT, Lee CR, Mitchell-Olds T. Life-history QTLS and natural selection on flowering time in Boechera stricta, a perennial relative of Arabidopsis. Evolution. 2011;65(3):771-87.

41. Salomé PA, Bomblies K, Laitinen RA, Yant L, Mott R, Weigel D. Genetic architecture of flowering-time variation in Arabidopsis thaliana. Genetics. 2011;188(2):421-33.

42. Strange A, Li P, Lister C, Anderson J, Warthmann N, Shindo C, Irwin J, Nordborg M, Dean C. Major-effect alleles at relatively few loci underlie distinct vernalization and flowering variation in Arabidopsis accessions. PLoS One. 2011;6(5):e19949.

43. Grillo MA, Li C, Hammond M, Wang L, Schemske DW. Genetic architecture of flowering time differentiation between locally adapted populations of Arabidopsis thaliana. New Phytol. 2013;197(4):1321-31.

44. Michaels SD, He Y, Scortecci KC, Amasino RM. Attenuation of FLOWERING LOCUS C activity as a mechanism for the evolution of summer-annual flowering behavior in Arabidopsis. Proc Natl Acad Sci USA. 2003;100(17): 10102-7.

45. Sánchez-Bermejo E, Méndez-Vigo B, Pico FX, Martínez-Zapater JM, AlonsoBlanco C. Novel natural alleles at FLC and LVR loci account for enhanced vernalization responses in Arabidopsis thaliana. Plant Cell Environ. 2012;35(9): 1672-84.

46. Irwin JA, Soumpourou E, Lister C, Ligthart JD, Kennedy S, Dean C. Nucleotide polymorphism affecting FLC expression underpins heading date variation in horticultural brassicas. Plant J. 2016;87(6):597-605.

47. Zhao J, Kulkarni V, Liu N, Pino Del Carpio D, Bucher J, Bonnema G. BrFLC2 (FLOWERING LOCUS C) as a candidate gene for a vernalization response QTL in Brassica rapa. J Exp Bot. 2010;61(6):1817-25.

48. Hou J, Long Y, Raman H, Zou X, Wang J, Dai S, Xiao Q, Li C, Fan L, Liu B. A Tourist-like MITE insertion in the upstream region of the BnFLC. A10 gene is associated with vernalization requirement in rapeseed (Brassica napus L.). BMC Plant Biol. 2012;12(1):238

49. Wu J, Wei K, Cheng F, Li S, Wang Q, Zhao J, Bonnema G, Wang X. A naturally occurring InDel variation in BraA. FLC. b (BrFLC2) associated with flowering time variation in Brassica rapa. BMC Plant Biol. 2012;12(1):151.

50. Johanson U, West J, Lister C, Michaels S, Amasino R, Dean C. Molecular analysis of FRIGIDA, a major determinant of natural variation in Arabidopsis flowering time. Science. 2000;290(5490):344-7.

51. Shindo C, Aranzana MJ, Lister C, Baxter C, Nicholls C, Nordborg M, Dean C. Role of FRIGIDA and FLOWERING LOCUS C in determining variation in flowering time of Arabidopsis. Plant Physiol. 2005;138(2):1163-73.

52. Österberg MK, Shavorskaya O, Lascoux M, Lagercrantz U. Naturally occurring indel variation in the Brassica nigra COL1 gene is associated with variation in flowering time. Genetics. 2002;161(1):299-306.

53. Marquardt S, Raitskin O, Wu Z, Liu F, Sun Q, Dean C. Functional consequences of splicing of the antisense transcript COOLAIR on FLC transcription. Mol Cell. 2014;54(1):156-65.

54. Swiezewski S, Liu F, Magusin A, Dean C. Cold-induced silencing by long antisense transcripts of an Arabidopsis Polycomb target. Nature. 2009; 462(7274):799.

55. Castaings L, Bergonzi S, Albani MC, Kemi U, Savolainen O, Coupland G. Evolutionary conservation of cold-induced antisense RNAs of FLOWERING LOCUS C in Arabidopsis thaliana perennial relatives. Nat Commun. 2014;5:4457.

56. Li X, Zhang S, Bai J, He Y. Tuning growth cycles of Brassica crops via natural antisense transcripts of BrFLC. Plant Biotechnol J. 2016;14(3):905-14.

57. Li P, Filiault D, Box MS, Kerdaffrec E, van Oosterhout C, Wilczek AM, Schmitt J, McMullan M, Bergelson J, Nordborg M. Multiple FLC haplotypes defined by independent cis-regulatory variation underpin life history diversity in Arabidopsis thaliana. Genes Dev. 2014;28(15):1635-40.

58. He Y, Michaels SD, Amasino RM. Regulation of flowering time by histone acetylation in Arabidopsis. Science. 2003;302(5651):1751-4. 
59. Ishizawa M, Kobayashi Y, Miyamura T, Matsuura S. Simple procedure of DNA isolation from human serum. Nucleic Acids Res. 1991;19(20):5792.

60. Okazaki K, Sakamoto K, Kikuchi R, Saito A, Togashi E, Kuginuki Y, Matsumoto S, Hirai M. Mapping and characterization of FLC homologs and QTL analysis of flowering time in Brassica oleracea. Theor Appl Genet. 2007;114(4):595-608.

61. https://www.ebi.ac.uk/Tools/msa/clustalo/ accessed on 20.01.2018.

62. Zhang B, Hu Z, Zhang Y, Li Y, Zhou S, Chen G. A putative functional MYB transcription factor induced by low temperature regulates anthocyanin biosynthesis in purple kale (Brassica oleracea var. acephala f. tricolor). Plant Cell Rep. 2012;31(2):281-9.

63. Nawaz I, lqbal M, Hakvoort HW, Bliek M, de Boer B, Schat H. Expression levels and promoter activities of candidate salt tolerance genes in halophytic and glycophytic Brassicaceae. Environ Exp Bot. 2014;99:59-66.

64. Lee J, Yang K, Lee M, Kim S, Kim J, Lim S, Kang G-H, Min SR, Kim S-J, Park SU. Differentiated cuticular wax content and expression patterns of cuticular wax biosynthetic genes in bloomed and bloomless broccoli (Brassica oleracea var. italica). Process Biochem. 2015;50(3):456-62.

Ready to submit your research? Choose BMC and benefit from:

- fast, convenient online submission

- thorough peer review by experienced researchers in your field

- rapid publication on acceptance

- support for research data, including large and complex data types

- gold Open Access which fosters wider collaboration and increased citations

- maximum visibility for your research: over $100 \mathrm{M}$ website views per year

At BMC, research is always in progress.

Learn more biomedcentral.com/submissions 